\title{
Obedience to Doctrine in Canon Law: The Legal Duty of Intellectual Assent
}

\author{
Norman Doe *
}

Interest in canon and ecclesiastical law has grown in recent years not least through the establishment in the Church of England of the Ecclesiastical Law Society (and its journal) in 1987. This has been, in part, a response to the need to promote the study of an aspect of church life that has undergone substantial development in the last thirty years. The period had seen the revision of the Church of England's canons (in the 1960's), an increase in decisions of the ecclesiastical courts in the exercise of their faculty jurisdiction, and the very large body of legislation created by the General Synod since its reform in 1969 in so many areas, synodical government, clerical discipline, relations with other churches, the care of cathedrals, legal aid for ecclesiastical litigation and the continuing debate over the ordination of women. This period has also seen the re-structuring of many of the constitutions of national churches in the Anglican Communion and, very significantly, the revision in 1983 of the Code of Canon Law of the Roman Catholic Church and the revision in 1991 of the Code of Canons of the Eastern (Catholic) Churches.

The study of canon law has been neglected in British universities since it was banned at the Reformation in the sixteenth century. Though there is a compulsory study for those training for the Roman Catholic priesthood, Anglican ordinands in England and Wales receive no formal, comprehensive and systematic training in canon law, nor do practitioners of church law, such as diocesan chancellors, diocesan registrars, and archdeacons. Standing as it does at the intersection of law and theology, as an object of scholarship canon law commends itself thoroughly. The central areas of concern in canon law, the law created by churches for themselves, the law created by the state for the church (sometimes known as the public ecclesiastical law) and - according to some definitions - the law created by God for the church, might be viewed and analysed from so many perspectives. Indeed, one of the achievements of the Ecclesiastical Law fournal, of the Church of England, in recent years has been the analysis of church law from the perspectives

* Course Director of the LL.M. in Canon Law, Cardiff Law School, University of Wales. I should like to express my gratitude to Miss Michelle Gooden, a summer research assistant at the Cardiff Law School, for her kind help in identifying many of the materials which form the basis of the discussion in this paper and for her help in clarifying some of the central ideas examined. 
of theology, past canonical practices, its ecumenical comparisons with other systems of canon law, comparisons with the civil law, and with the central Christian theological doctrines. ${ }^{1}$ The scope of canon law is wide-ranging. Essentially, however, in addition to the host of jurisprudential questions that might be asked of canon law (its basic authority, its justification and purposes), the main principles and rules of canon and ecclesiastical law may be categorised as dealing with constitutional church government, the powers and limitations on ecclesiastical institutions, with rights and duties of ecclesiastical persons, with the legality of liturgical practices and the creation and regulation of forms of worship, with the regulation by law of the sacraments and other church services, particularly of admission to and exclusion from these, with the rules governing church property and with the relation between church and civil law. ${ }^{2}$

The area of concern in this short paper is that of doctrine and the teaching authority of the church. This is, in itself, a very large subject and has since Vatican II seen in the Roman Catholic Church a significant shift in canon law from the idea that the right to formulate and present church doctrine for public view is one vested in the ecclesiastical hierarchy (in the pastors of the church), to one in which all the faithful, lay and clerical, possess a magisterial function. ${ }^{3}$ One particular area of the law relating to doctrine is that of the authority which canon law ascribes to different forms of doctrine as produced by the various ecclesiastical institutions whether doctrines produced by institutions in the church are of sufficient authority to impose on the church member the duty of intellectual obedience to them, and the obligation not to dissent, either privately or publicly.

The issue has acquired considerable topical interest in recent years in the Church of England over the public statements of the Bishop of Durham in 1988 and his so-called 'trial-by-synod', when the General Synod was called on but refused to condemn views which were considered by many to have challenged the Church of England's teaching on the Resurrection and the Virgin Birth. In the Roman Catholic Church, the issue has come to the fore over the church's treatment in recent years of the celebrated theologians Hans Küng, Edward Schillebeeckx, and Johannes Baptist Metz. The Belgian Edward Schillebeeckx, a professor of theology at the Catholic University of Nijmegen in Holland,

1. N. Doe, "Toward a critique of the role of theology in English ecclesiastical and canon law", 2 Ecclesiastical Law foumal (1992), pp. 328-346.

2. For definitions of canon and ecclesiastical law, and its scope and object, see N. Doe (ed.), Essays in Canon Law: A Study of the Law of the Church of Wales (University of Wales Press, Cardiff, 1992), pp. 69-74. For a definition by the Church of England canonist Garth Moore, see B. Hanson and T. Briden (eds.), Moore's Introduction to English Canon Law 3rd edition (1992), pp. 1-9; for a Roman Catholic definition, see G. May "Ecclesiastical law", K. Rahner (ed.), Encyclopedia of Theology (1981), p. 395, and P. Huizing, "Church and state in public ecclesiastical law", Concilium 8(6) (1970), 126 at p. 129. 3. J. A. Coriden, T. J. Green, and D. E. Heintschel, The Code of Canon Law: $A$ Text and Commentary (1985) 345f. See also, generally, J. A. Coriden, Introduction to Canon Lawo (1991), pp. 103-111, and H. Fries, "Is there a magisterium of the faithful?", Concilium (1981) 177. 
published in 1974 a book, fesus: An Experiment in Christology, in which he argued that though Jesus' existence was 'wholly the work of God's spirit' the virgin birth was simply a story devised after the event to express that truth through the imagery of a prophesy found in Isaiah (7:14). Schillebeeckx also wrote of the disciples' faith as being derived from their experience of the grace of forgiveness, not from a 'crude and naive realism' of a physical resurrection. After a five-year investigation he was summoned to and exonerated by a 'colloquium' of the Vatican's Congregation for the Doctrine of the Faith in 1979.4 At the same time, the Swiss-born Hans Küng's Infallible? An Inquiry, published in 1970, resulted in a judgment of the Vatican that he was no longer to be approved as a theologian allowed to teach at the Catholic theology faculty at the University of Tubingen. ${ }^{5}$ Again, in 1979 Father Johannes Baptist Metz, the liberation theologian, was offered a chair at Munich but the Archbishop of Munich, Cardinal Ratzinger, exercised his power of veto under a 1924 church-state concordat to block the appointment. The problem has also become important bearing in mind the Roman Catholic Church's efforts to incorporate Vatican II's declarations on the place of human rights in the church and the 1983 Code's recognition and protection of these, including that of freedom of thought and expression, as flowing from the dignity of the human person as well as from incorporation into the church through baptism. ${ }^{6}$

Our basic problem is the extent to which canon law confers upon exercises of teaching authority, in the Roman Catholic Church and in the Church of England, the power to require intellectual assent, and therefore compliance in the form of conduct, with doctrinal statements formulated by those churches. Related to this, of course, is the question of the canonical right to dissent from authoritative doctrines and the way in which this right is expressed and protected. There may be two basic forms of dissent: a private intellectual withholding of assent; and a public withholding of assent expressed in a positive challenging of or attack upon the doctrine of the church. We shall examine here, in outline, the legal position of assent to and dissent from ecclesiastical doctrines under the canonical systems of the Roman Catholic Church and the Church of England.

\section{Roman Catholic Canon Law: assent and dissent}

Though Roman Catholic canon law confers upon all the faithful, lay and cleric, the

4. See generally F. A. Sullivan, Magisterium: Teaching Authority in the Catholic Church (Dublin, 1983), p. 217.

5. For a general survey see H. Haring and K-J. Kuschel (eds.), Hans Küng: His Work and His Way (Glasgow, 1979), pp. 79-101.

6. C. Lara, "Some general reflections on the rights and duties of the Christian faithful", Studia Canonica 20(1) (1986) 7; D. J. Ward, "The rights of Christians within the code of canon law", in J. Hite and D. J. Ward (eds.), Readings, Cases, Materials in Canon Law (Collegeville, Minnesota, 1990), p. 179, and J. Langan, "Can there be a human rights problem in the Church?", 46 The furist (1986), p. 1. For the position before the 1983 code, see, e.g., P. Lombardia, "The fundamental rights of the faithful", Concilium, 8(5) (1969) 42. 
right to present the Christian doctrine for public view, ${ }^{7}$ it confers power to formulate doctrine only upon the magisterium, the clerical teaching authorities of the church. By Canon 749 of the 1983 Code canon law recognises, as a divine institution, the right of the pope unilaterally, and the college of bishops collectively (when gathered together in an ecumenical council, or whilst dispersed throughout the world), the power to formulate infallible or definitive doctrine. When the pope or college of bishops create definitive doctrine in matters of faith and morals, they do so under an exercise of supreme magisterial authority: this is an exercise of the universal extraordinary magisterium. By Canon 750 the pope or the college of bishops might formulate definitive doctrine when they declare that a doctrine (as one contained in or derived from the 'deposit of faith') has been divinely revealed. Canon 752 allows for the creation of a lesser species of authoritative doctrine in matters of faith and morals, non-definitive doctrine, formulated by the pope or college of bishops exercising their ordinary universal magisterium. And Canon 753 allows the bishops, who individually do not possess infallible teaching authority, to create non-definitive doctrine in matters of faith. By canon law, then, these different species of doctrine enjoy different types of authoritative status in the Roman Catholic Church. One fundamental question is the response each of these forms of doctrine requires from those to whom they are addressed, in particular the members of the church.

\section{Definitive doctrines}

In relation to definitive doctrines, when the magisterium formulates a doctrine infallibly, by canon law this gives rise to an apparently absolute duty of assent, an assent of faith. Infallible doctrines are themselves irreformable and possess supreme authority. In relation to doctrines formulated under Canon 750 the doctrine is authoritative because it represents simply a declaration of a truth entrusted to the church by Christ or the apostles. Such doctrines "must be believed with divine and catholic faith". As Francis Sullivan puts it: "the motive of the act of faith is not the reliability of the human messenger, but the truth of the word itself as word of God." ${ }^{8}$ According to Canon 749 infallible doctrines must be "held definitively". According to the documents of Vatican II, when the magisterium defines a doctrine, it must "be adhered to with the submission of faith". 9 The infallible doctrine of the bishops dispersed "must be held conclusively".

There is on the face of it no right of intellectual dissent. Once it has been

7. See Coriden, Green and Heintschel, Commentary, Canons 211, 225, 226, 747, 781. According to Canon 211: "All the Christian faithful have the duty and the right to work so that the divine message of salvation may increasingly reach the whole of humankind in every age and in every land."

8. F. A. Sullivan, "Magisterium", in J. A. Komonchak, M. Collins, and D. A. Lane (eds.), The New Dictionary of Theology (1987), p. 617.

9. A. Flannery (ed.), Vatican Council II: The Conciliar and Postconciliar Documents, Vol. 1 (New York, 1988), p. 379 (for the dogmatic constitution Lumen Gentium (1964) 25). 
declared as definitive, the doctrine requires an assent of faith: it must be held as definitive and true by the faithful member. When the magisterium gives a definitive judgment on a matter of faith this "puts an end to freedom of opinion on the matter" - it becomes "the normative faith of the community". ${ }^{10}$ Thus, for example (and this was an issue in the debate over Hans Küng), members of the Roman Catholic Church are under a legal duty to give an assent intellectually to the idea that when a pope pronounces a definitive judgment he is gifted by the Holy Spirit with that infallibility which Christ endowed the church in defining matters of faith and morals. This doctrine itself was declared infallibly by Vatican I: it is an irreversible doctrine, and canon law requires an irreversible assent to it from the faithful. ${ }^{11}$

Here the only possible right of dissent is based on technical, and largely theoretical, challenges to the exercise of the infallible magisterium as being canonically ultra vires. For example, if the doctrine is to be treated and obeyed as infallible, the magisterial authorities under Canon 749 must declare it as such. If it is not declared as definitive it may not give rise to an absolute assent of faith. If the subject-matter of the doctrine is not one concerning faith and morals, then the doctrine may not give rise to an absolute assent. If the magisterial authority was coerced, or was not elected lawfully, or ordained unlawfully, then similarly the duty of assent may not arise as, canonically, this will not properly speaking be an infallible exercise of the magisterium.

\section{Non-definitive doctrines}

When a doctrine is non-definitive, formulated by the church's ordinary magisterium, under the 1983 Code it too possesses an authority and it has an obligatory nature. The declaration Lumen Gentium (1985) of Vatican II, itself a non-definitive doctrine (because the council chose not to create definitive doctrine), stresses that non-definitive doctrines impose the obligation of "respect and submission of the will and mind" and the duty "to adhere sincerely" to them. A papal encyclical is a typical medium for the expression of non-definitive doctrine. No pope has claimed to teach infallibly in an encyclical. ${ }^{12}$ When, for example, Paul VI's encyclical Humanae Vitae (1986) reiterates the ban on contraception, this piece of doctrine, via the duties imposed by canon law, requires not only some form of intellectual assent (about the rightness of the papal moral teaching), but also an external response, a form of conduct on the part of the faithful. This piece of ecclesiastical doctrine therefore has a quasi-legal nature: in

10. F. A. Sullivan, Magisterium, pp. 79-118.

11. K. Rahner, "Magisterium", in K. Rahner (ed.), Encyclopedia of Theology (1981), p. 871. See generally, T. Horvath, "A structural understanding of the magisterium of the church", Science et Esprit, 29(3) (1977) 283, and W. M. Thompson, "Authority and magisterium in recent Catholic thought", Chicago Studies (1977) p. 278.

12. F. A. Sullivan, Magisterium, p. 155. 
conjunction with the canon law, which requires some form of obedience to the doctrine, the doctrine is to be treated as if it were law. ${ }^{13}$

Roman canonists are not in agreement, however, about the precise obligation canon law places on the faithful with regard to non-definitive doctrine. The crucial word in the canons is obsequium. Canon 752 has been translated by the Canon Law Society of America as imposing a "religious respect of intellect and will, even if not the assent of faith" on the faithful towards non-definitive doctrine created by the pope or the college of bishops. Again, Canon 753 is translated as imposing an obligation of "religious respect" to the non-definitive doctrines of individual bishops or conferences of bishops in matters of faith. If the obligation, if obsequium, is interpreted in this way, then there seems to be scope, arguably, for the right of dissent to operate in relation to non-definitive doctrines of the magisterium. When the encyclical on contraception imposes rules of conduct as well as a mental acceptance of the moral propriety of the teaching in it, there is, then, on this translation, no absolute duty of obedience. Indeed, this is the understanding of B. C. Butler: 'due respect' only is owed to such teaching, an interpretation also favoured by the Italian translators of the expression (ossequio); the Italian edition of Lumen Gentium actually translates obsequium as rispetto. ${ }^{14}$

However, other translations of the term suggest that the duty under Canon 752 is stronger. It imposes an obligation of obedience, not simply respect. The term 'submission' is used by the Canon Law Society of Great Britain and Ireland in its translation of obsequium, the French translation uses soumission, and the German Gehorsam. Indeed, this understanding is close to the view of Pius XII in his 1950 encyclical Humani Generis. As to the question at issue in the encyclical, the pope stated that it "can no longer be considered a subject for free debate." This too is the view of Francis Sullivan who points to the principle appearing in Lumen Gentium that the faithful must "sincerely adhere" (adhaerere) to such doctrines. ${ }^{15}$ In short, it is unclear from the text of the Code itself whether the duty imposed on the faithful is merely to respect such doctrines or to submit the will and mind to them in obedience.

The question remains, therefore, whether a member of the faithful might dissent intellectually and in conduct from such doctrines. After all, as nondefinitive doctrine is just that, reformable, open to error and not an exercise of solemn infallible teaching authority, or it is not the intention of the doctrine-maker for the doctrine to be binding, it is arguable that the individual is free to dissent.

13. Sullivan is of the view, however, that (a doctrinal document such as) 'Humanae Vitae is not Church law', because law does not require an intellectual response, an acceptance of its moral worth: ibid., $p$. 162. For the connection between doctrine and canon law in Roman Catholic thought, see T. Urresti, "Canon law and theology: two different sciences", Concilium, 8(3) (1967) 10.

14. B. C. Butler, "Infallible; authenticum; assensus; obesquium. Christian teaching authority and the Christian's response", Doctrine and Life, 31 (1981) 77. See also the first class survey by F. A. Sullivan. "The response due to the non-definitive exercise of magisterium", Studia Canonica, 23 (1989) 267, at p. 268.

15. F. A. Sullivan, Magisterium, pp. 158-166. 
The matter is made a little clearer, that the obligation imposed by Canon 752 allows scope for internal dissent, by some official statements and the opinions of some 'approved authors'. The view of the Sacred Congregation for the Doctrine of the Faith from 1988 (whilst investigating the American Father Charles Curran's attack on the encyclical Humanae Vitae on birth control) was that a person may have a right to private dissent from such doctrines if there is a "personal certitude that the teaching of the Church is incorrect." 16 Similarly, in the opinion of the approved authors Palmieri (writing in 1891), Pesch (writing in 1924) and Lercher (writing in 1951), there was a possibility of legitimate non-assent to authoritative but non-infallible papal teaching if the individual had "reasons that are persuasive (even if inculpably erroneous)"; a person could dissent if there were "sufficient reasons for doubting", or if he had "grave suspicion that the presumption of truth which official teaching enjoys is not verified in this case."17 Though this is not stated in the code itself, and in a legal system that does not employ a doctrine of binding judicial precedent, it must be remembered that in interpreting the code recourse might be had, under Canon 19, to "the common and constant opinion of learned writers".

\section{The explicit right of dissent}

We have so far attempted to construct a right to dissent by concentrating on the elements of the duty of assent, and the uncertainties surrounding the meaning of obsequium. The right to dissent privately and publicly from the church's authoritative doctrines may be found, however, in the code's lists of fundamental rights enjoyed by all the faithful - rights which may be vindicated judicially in the ecclesiastical courts of the Roman Catholic Church. And here we meet a basic tension in Roman Catholic canon law, for, under Canon 754, "All the Christian faithful are obliged to observe the constitutions and decrees which the legitimate authority of the Church issues in order to propose doctrine and proscribe erroneous opinions."

First, freedom of intellectual dissent from doctrine is conferred by Canon 748: "Persons cannot ever be forced by anyone to embrace the Catholic faith against their conscience." This canon does not apply to the expression of opinions contrary to the teaching of the church. It relates only to the mind of the individual. The commentaries on this canon are not very satisfactory. The canon is taken from Vatican II's Declaration on Religious Liberty, Dignitatis Humanae (1965). This states that the right to religious freedom is based on the "very dignity of the human person": it is a human right which canon law merely presents. Though "endowed with reason and free will", individuals are bound by a "moral obligation" to seek the truth and "to adhere to the truth once they come to know it and direct their

16. C. E. Curran, Faithful Dissent (Kansas City, 1986), pp. 201-202.

17. For a discussion of D. Palmieri's Tractatus de Romano Pontifice cum prolegomeno de Ecclesia (1891), C. Pesch's Praelectiones dogmaticae (1924), and L. Lercher's Institutiones theologicae dogmaticae in usum scholarum (1951), see Sullivan's article in Studia Canonica 23 (1989) 267, at pp. 276-78. 
lives in accordance with the demands of truth." But individuals cannot be forced to this. "For this reason the right to this immunity continues to exist even in those who do not live up to their obligation of seeking the truth and adhering to it." The declaration states that "It is through his conscience that man sees and recognises the demands of the divine law. He is bound to follow his conscience faithfully in all his activity so that he may come to God ... Therefore he must not be forced to act contrary to his conscience... especially in religious matters. The reason is because the practice of religion of its very nature consists primarily of those voluntary and free internal acts by which a man directs himself to God." 18 Though expressed in absolute terms in relation to definitive doctrine, it appears that, ultimately, even the canonical duty to assent to this is unenforceable.

Secondly, there is the right to express publicly opinions contrary to church doctrine. By Canon 212(3), the faithful have "the right and even at times the duty to manifest to the sacred pastors their opinion on matters which pertain to the good of the Church." The canon also provides that the faithful "have a right to make their opinion known to the other Christian faithful." As James Provost suggests, however, this explicit right to express opinion is not unfettered. ${ }^{19}$ It is a right to which several duties are attached, first and foremost the limitation relating to subject-matter. The individual may express an opinion only regarding the good of the church - but the code does not explain this. Provost is of the view, though, that such opinions "could be favourable or critical."

This right, with this limitation, simply allows the expression of an opinion, which may be an opinion about the church's doctrine. Here there is an apparent contradication in the canon law. The law allows a faithful member to express an opinion which might contradict the teaching of the church. By implication, one might think that the canon therefore allows the individual to 'hold' intellectually an opinion contrary to the teaching of the church. However, because of the duty of assent (or respect), this is unlikely to be the meaning of the canon. When the individual expresses an opinion about the church's doctrine he is exercising a canonical right. But also the canon law requires that person to assent to that doctrine intellectually. The commentaries are not helpful on this point. Presumably one has the right to express another's opinion, or an opinion which one does not hold. Or else this canon is an exception to the duty of submission and within its terms one may (according to the view of Pesch, for example) still hold contrary opinions if there is a good reason. In any event, there are other limitations envisaged by Canon 212 . When they express these opinions, the faithful are under a canonical duty to have "due regard for the integrity of faith and morals and reverence towards their pastors, and [have] consideration for the common good and the dignity of persons."

A third right is conferred by the code upon theologians: the right of free inquiry 
and theological expression and dissent and an autonomous right of academic freedom to those engaged in theological study. Canon 218 is drawn from Vatican II's Gaudium et Spes (1966). It states: "Those who are engaged in the sacred disciplines enjoy a lawful freedom of inquiry and of prudently expressing their opinions on matters in which they have expertise, while observing a due respect for the magisterium of the Church." Unlike the other rights, this is not described or treated as a 'human right': it is merely treated as a kind of concession, a 'lawful freedom'. It is, as such, changeable and able to be destroyed. The canon applies to those involved in studies in seminaries and universities. Both clergy and laity are given this right. Provost's view of the canon is that "At the very least, the ecclesiastical magisterium must be acknowledged and taken into serious consideration in expressing theological opinions." But, he says, "This does not rule out dissent", when this is based on respect. ${ }^{20}$ The International Theological Commission's Theses on the relationship between the ecclesiastical magisterium and theology (1975) are helpful here. These set out guidelines for dissent: dissent is possible if it is grounded in a "true respect for the magisterium even while disagreeing with it on a particular point." And this was the view of Cardinal Joseph Ratzinger who, in 1969, maintained that "Criticism of papal pronouncements will be possible and even necessary, to the degree that they lack support in Scripture and the Creed, that is, in the faith of the whole Church."21

Thirdly, the right to dissent may be latent within defences to doctrinal offences under Roman Catholic canon law. The code distinguishes two doctrinal offences. First, the code creates four basic offences against religion and the unity of the Church. Canon 751 states: "Heresy is the obstinate post-baptismal denial of some truth which must be believed with divine and catholic faith, or it is likewise an obstinate doubt concerning the same." The canon defines apostacy as "the total repudiation of the Christian faith." Schism is "the refusal of submission to the Roman Pontiff or of communion with the members of the Church subject to him." And blasphemy is an offence under Canon 1369: "A person who uses a public show or speech, published writings, or other media of social communication to blaspheme, seriously damage good morals, express wrongs against religion or against the Church or stir up hatred or contempt against religion or the church is to be published with a just penalty."

These definitions are much the same as the 1917 code. The revisers of the code made the point that they may be committed, though the code does not say this,

20. Ibid., pp. 151-2. See also P. Huizing and $\mathrm{K}$. Walf, "What does the 'right to dissent" mean in the Church?", Concilium 158 (1982) 3, and H. Haring, "The rights and limits of dissent", ibid., 95, and J. Provost, "The Catholic Church and dissent", ibid., p. 13.

21. The official Latin Text of the Theses, with a commentary by $O$. Semmelroth and $\mathrm{K}$. Lehmann, is published in Gregorianum 57 (1976), pp. 549-63. An English translation is to be found in C. E. Curran and R. A. McCormick (eds.), Readings in Moral Theology No. 3: The Magisterium and Morality (New York, 1982), pp. 151-170. See also R. M. Gula, "The right to private and public dissent from specific pronouncements of the ordinary magisterium", Eglise et Theologie 9 (1978), p. 319. 
only when there is evidence of 'bad faith'. If the denial or repudiation is not in bad faith, then this does not amount to heresy or apostacy. Arguably, therefore, there is a right to repudiate or deny in good faith - but this is not defined. Also, in relation to heresy, the denial or doubt must be "obstinate" - pertinax - prolonged over a period. And heresy may be committed only in relation to those doctrines formulated under Canon 750 - doctrines presented as part of the revealed deposit of faith. It does not apply to a rejection or denial of non-definitive doctrine. One presumes that a person still has the right to dissent from non-definitive doctrines without becoming a heretic. The penalties for heresy, apostacy or schism, found in Canon 1364, are automatic excommunication for lay people and for clerics, excommunication or suspension, deprivation, or penal transfer. In addition to these the general defences in Canons 1323 and 1324 may be available - unwitting or accidental violation of law, violation out of ignorance, fear or necessity, for instance. The second category of doctrinal offences are those committed against church authorities. According to Canon 1371, the following are to be punished with a just penalty: "A person who teaches a doctrine condemned by the Roman Pontiff or by an ecumenical council"; also, "a person who pertinaciously rejects the doctrine mentioned in Canon 752 and who does not make a retraction after having been admonished by the Apostolic See or by the ordinary." In other words, it is an offence, punishable with a just penalty (which may include excommunication), to violate the duty of assent/respect imposed by Canon 752 . Canon 1371 creates, therefore, it seems, two offences: one public - the expression or teaching of doctrines contrary to those of the pope or council; and the other private - the failure to assent to non-definitive doctrines of the ordinary magisterium. This is a new doctrinal offence: dissent from the ordinary, nonfallible magisterium. However, if the individual retracts his dissent, then he does not suffer a sanction. The practical effect, then, is that there is still in fact a right to dissent, for the period of dissent, if the offender subsequently makes a retraction. Also, if a person does not assent for the reasons spelt out in Canons 1323 and 1324 he will be excused from sanctions.

\section{The Church of England}

The Roman canon law governing the creation of doctrine, its authoritative status, and the response due from its recipients, certainly gives rise to an obligation on the part of the faithful; at least to respect that doctrine, at most to give an intellectual assent and a submission of the will to it. The right to dissent privately and publicly from such doctrines arises, though the canon law is not clear on this point, if the individual dissents in good conscience.

In Roman canon law it is a fairly straightforward task to identify the location of theological or doctrinal statements. The sources of Roman Catholic doctrine are clearly to be found in the deposit of faith, as transmitted in scripture and tradition, in the definitive pronouncements on faith produced by the universal magisterium, in the non-definitive doctrinal statements of the ordinary magisterium, in the 
constitutions, decrees, declarations, encyclicals, and pastoral letters of popes, the college of bishops, of individual bishops, of conferences of bishops.

\section{The doctrine of the Church of England}

Whereas Roman canon law expresses a developed idea of official doctrines, issuing from the supreme and ordinary magisterium, the law of the Church of England is, at first sight, rather simpler. Canon A5 of the Revised Canons Ecclesiastical 1964-70 makes the general claim that the doctrine of the Church of England "is to be found in the Thirty-Nine Articles of Religion, the Book of Common Prayer, and the Ordinal." The canon also spells out the source of these doctrinal documents and also their extra-legal, their theological, authority. "The doctrine of the Church of England is grounded in the Holy Scriptures, and in such teachings of the ancient fathers and Councils of the Church as are agreeable to the said Scriptures." This canonical definition (by means of sources) of the doctrine of the Church of England has been given legislative approval indirectly by s.5(1) of the Church of England (Worship and Doctrine) Measure 1974: "References in this Measure to the doctrine of the Church of England shall be construed in accordance with the statement concerning that doctrine contained in the Canons of the Church of England."

Garth Moore was of the opinion that the theological doctrine of the Church of England "is that of the Western Catholic church immediately before the Reformation", as modified at the time of the Reformation and since. Thus, at least in part, its doctrine is contained in the Book of Common Prayer, in the ThirtyNine Articles, in the canons of 1603 and 1969, in the Homilies, in "Acts of Parliament and ... the judgments of the courts." Moore maintained that "All these in varying degrees may be said to be authoritative - not necessarily right, but binding until altered."'22

Whereas the Roman church law claims for its definitive doctrines infallibility, the law of the Church of England does not. By law, Church of England doctrines are closer to the Roman canonical 'non-definitive' doctrines of the ordinary magisterium: they may not be true but they possess 'some' authority. The proposition that these doctrines of the Church of England are 'legally approved' simply means that the law recognises this as the doctrine of the Church of England. This is the law's first function - definition - to define what are the church's doctrines. A second consequence is that the doctrines contained in the Thirty-Nine Articles and in the Prayer Book can be altered only by act of parliament or synodical measure. ${ }^{23}$ Under the 1974 measure, the synod may make new forms of worship "but the powers of the General Synod under this subsection shall be so exercised as to ensure that the forms of service contained in the Book of Common Prayer continue to be available for use in the Church of England."

22. T. Briden and B. Hanson (eds.), Moore's Introduction to English Canon Law 3rd. ed. (1992), pp. $49-50$.

23. Halsbury's Laws of England, Vol. 14, Ecclesiastical Law 4th ed., (1975), paras. 335, 936, n. 3. 
Other doctrines, contained for example in the resolutions of Lambeth Conferences, those of the General Synod (such as emerged in the David Jenkins' debate), acts of Convocations, and reports of Commissions fall into the category of persuasive doctrinal authorities. As the Anglican Communion has no central legislative body, the Lambeth Conferences have repeatedly asserted that its doctrinal statements are merely guidelines and not binding. ${ }^{24}$ As Halsbury puts it: such doctrines "have thereby derived on a consensual basis an authoritative character in the churches which have accepted them." 25 Indeed, one of the difficulties in determining the authority of doctrines outside those legally approved is the view (endorsed by, for example, the Church of England's Doctrine Commission in 1922) that: "There is not, and the majority of us do not desire that there should be, a system of distinctively Anglican theology."26

Unlike definitive doctrines in Roman Catholic canon law, the Preface to the Book of Common Prayer 1662 and the Thirty-Nine Articles 1571 both lay down the basic principle that ecclesiastical doctrine is reformable. ${ }^{27}$ Upon this basic idea a legal principle has emerged applicable to the established church. It is no better spelt out than by the House of Lords in General Assembly of the Free Church of Scotland v. Lord Overton (1904): "where the state has by legislative acts established a church identified by certain doctrines, that church cannot, while retaining the benefit of establishment, exercise any power of altering those doctrines without the legislative sanction of the state." Lord Halsbury stressed in the case that "it is to be remembered that a court of law has nothing to do with the soundness or unsoundness of a particular doctrine." 28 This principle has been applied of course to the Church of England. Indeed, the whole assumption behind the litigation in Brown et al v. Runcie et al (1991) was that procedures for the creation of doctrine imposed by legislation must be followed. ${ }^{29}$

Today, though parliament may create, approve or amend doctrine (indeed, in 1928 it was parliament that blocked the revision of doctrine contained in the proposed prayer book), it is primarily the General Synod which may formulate legally approved doctrine. But it is not an unfettered power. The Church of England (Worship and Doctrine) Measure (s.4) imposes a self-limiting substantive

24. G. R. Evans and J. R. Wright (eds.), The Anglican Tradition: A Handbook of Sources (1991), pp. 383, 389-390.

25. Halsbury, Ecclesiastical Law, para. 314.

26. See Evans and Wright, The Anglican Tradition, pp. 345, 401. See also Believing in the Church: The Corporate Nature of Faith: A Report by the Doctrine Commission of the Church of England (1981).

27. Art. XXXIV of the Thirty-Nine Articles of Religion (1571) states: "It is not necessary that traditions and ceremonies be in all places one, or utterly alike, for at all times they have been diverse, and may be changed of countries, times and man's manners." Also, "Every particular or national Church, has authority to ordain, change, and abolish ceremonies or rites of the Church ordained only by man's authority." See E. J. Bicknell, $A$ Theological Introduction to the Thirty-Nine Articles of the Church of England 2nd ed. (1925), pp. 376-388.

28. [1904] A.C. 515, at p. 648.

29. (1991) The Times, February 20. 
duty on the General Synod only to create forms of service (when these express doctrine), in every canon or regulation providing for worship, which are consistent with and not departures from the doctrine of the Church of England. When it creates new forms of service it is under a legislative duty to exercise its powers "to ensure that the forms of service contained in the Book of Common Prayer continue to be available for use" (s.1, 1974 measure). When doctrine is altered by measure, the measure must be referred under Schedule 2 of the 1969 Synodical Government Measure to the Synod's House of Bishops; the form of the measure for final approval must be that as approved by the bishops. The measure must then also be approved by the two convocations sitting separately before final approval by the Synod. When the alteration is by canon, such a canon might be submitted for royal licence and assent only if it has been approved by no less than a two-thirds majority in each house of Synod.

\section{The legal obligation of belief}

The Roman Catholic canonical duty of assent to definitive doctrines finds a parallel in the Church of England's basic principle (in Article VI of the ThirtyNine Articles) that only those doctrines which are contained in Holy Scripture, or "proved thereby" (deriving from scripture), require an assent of faith: only these must, according to the legally approved doctrine contained in the Thirty-Nine Articles, "by law", be believed. Indeed, under Canon C15 in their declaration of assent, archbishops, bishops and clergy, are obliged to declare their "belief in the faith which is revealed in the Holy Scriptures." The law of the Church of England imposes the legal duty to give an assent of the intellect, a legal obligation of belief, to scriptural doctrines, or those deriving from scripture, upon all the faithful. In contrast, it imposes the obligation of intellectual assent to doctrines contained in the authoritative English theological documents only upon the clergy and lay office-holders in the Church of England, not upon the all faithful.

According to 5.2 of the Church of England (Worship and Doctrine) Measure 1974, "It shall be lawful for the general Synod to make provision by Canon with respect to the obligations of the clergy, deaconesses and lay officers of the Church of England to assent or subscribe to the doctrine of that Church and the forms of that assent or subscription which may include an explanatory preface." As Halsbury points out, under the Clerical Subscription Act 1865, "formerly no clergyman could be ordained or hold a living or curacy without making his declaration of assent to them." However, this has been repealed by the synod's 1974 measure (Schedule 1(1)).

Canon $\mathrm{C} 15$ of the revised canons of course sets out the terms of the modern declaration of assent that must be taken by clerics. The preface to the declaration states that the Church of England "professes the faith uniquely revealed in the Holy Scriptures and set forth in the catholic creeds ... it [the church] has borne witness to Christian truth in its historical formularies, the Thirty-Nine Articles of Religion, the Book of Common Prayer and the Ordering of Bishops, Priests and 
Deacons." The declaration imposes on clerics "loyalty to this inheritance of faith". Under Canon C15, archbishops, bishops and clergy are under a duty (the word used in the canon is "shall") to make this declaration of assent. This is a canonical duty of intellectual assent structured in a way very similar to the Roman Catholic duty of intellectual assent or submission incumbent on all the faithful.

As the canons, according to the principle stated in, for example, Bishop of Exeter v. Marshall (1868), are binding on the clergy in spiritual matters, assuming assent to doctrine is a spiritual matter, we might reasonably conclude that the clergy are under a legally enforceable duty, derived from the canons, to give intellectual assent to the doctrines contained in the Articles of Religion. ${ }^{30}$ In the event that they do not, this is the legal basis of possible disciplinary action effected executively or judicially or the occurrence of the other legal consequences. This is effectively what was attempted in Gorham v. Bishop of Exeter (1850). Gorham maintained, amongst other things, that infants were not made members of the church at baptism. The Queen's presentation of him, and his induction, was refused by the bishop. He held "unsound doctrines, contrary to the true christian faith, contrary to and inconsistent with the doctrine of the Church of England", against the Thirty-Nine Articles, the prayer book and so on. The Court of the Arches upheld the bishop's refusal to induct. Though the question for the Privy Council was jurisdictional - whether an appeal would lie to it or the Upper House of Convocation (it held that appeal did lie to the Privy Council) - the effect of the Arches' decision was that the cleric was to be disadvantaged for his lack of assent. ${ }^{31}$ Indeed, when the Worship and Doctrine Measure under s.4 recognises the Synod's power to create by canon the requirement for such declarations of assent, in so doing the Synod is bound to ensure, "as in the opinion of the general Synod", that these are "neither contrary to, nor indicative of any departure from, the doctrine of the Church of England in any essential matter."

The legal duty imposed on clergy to assent intellectually to the church's doctrines is also imposed, of course, on lay officers of the church. Under s.2(2) of the Worship and Doctrine Measure 1974 "'lay officers' means licensed workers, readers, lay judges of consistory or provincial courts, and lay holders of other offices admission to which is for the time being regulated by Canon." For example, the judicial ecclesiastical officer, the diocesan chancellor, is obliged under Canon G3 to assent "to the faith which is revealed in the holy scriptures and set forth in the Catholic creeds and to which the historic formularies of the Church of England bear witness" (Canon G3). The diocesan registrar must make the same declaration.

30. (1868) L.R. 3 H.L. 17.

31. (1850) Moore's Special Report $462 ;(1850)$ Eng. Repts. 177 : this report is not accurate and does not contain many of the judicial statements found in Moore's Special Report. For the unreliability of the English Reports see M. Smith, "On using the English Reports as a source for ecclesiastical law: a cautionary tale", 1(3) Ecclesiastical Law fournal (1988), p. 32. For a discussion of the history of the declaration of assent, the generality of modern declarations (and the scope for intellectual freedom), see the 1981 Doctrine Commission's Report Believing in the Church, pp. 129-134. 
Whereas clergy have a legal duty, via their declaration, to assent intellectually to the doctrines in the formularies and the Thirty-Nine Articles, the lay faithful are not under a legal duty to do so. Unlike Roman Catholic canon law which imposes the duty of intellectual assent, to definitive and non-definitive magisterial doctrine, on all the faithful, the laity of the Church of England simply have a 'right', not a duty, to assent intellectually to the legally approved doctrines. When it says that the Thirty-Nine Articles are agreeable to the Word of God, Canon A2 states that these articles "may be assented to with a good conscience by all members of the Church of England." Canon A3 also says, of course, that the form of worship contained in the Book of Common prayer, and by implication the doctrine contained in it, "may be assented to" by the church's members.

The principal effect of the rule that the laity have not got a duty of assent, is that they have a public legal right to private rejection of the church's doctrines. The law confers on them the right of free religious thought, even as members of the church. They have a legal right to withhold intellectual assent to the church's legally authoritative doctrines. (This is of course not a legal right enjoyed by Roman Catholics.) However, there may be a public obligation to assent. The moment at which a Church of England member publicly withholds assent, or challenges these doctrines, may have legal consequences. A public denial of these doctrines may result in the imposition of ecclesiastical sanctions - not necessarily enforceable judicially in the courts, but enforceable executively by the clergy such as refusal of admission to the sacraments.

\section{The right to dissent and doctrinal offences}

In the Church of England the law provides that an individual has a right to withhold intellectual assent to the doctrines of the church, and to disagree with that doctrine publicly, if this does not constitute an ecclesiastical doctrinal offence. Unlike Roman Catholic canon law, there is no separate and distinct right to dissent conferred explicitly by church law. As with the problem of rights in civil law, if it exists, the ecclesiastical right to dissent might be explained under the standard residualist theory of constitutional law. An individual has the right to contradict privately or publicly the legally approved doctrines of the Church of England insofar as their contradiction is not forbidden by church law.

The Ecclesiastical Jurisdiction Measure 1963, s.14, provides that proceedings may be instituted under the measure against any of the persons specified in $\mathrm{s} .17$ charging "(a) an offence against the laws ecclesiastical involving matters of doctrine, ritual and ceremonial." Proceedings for doctrinal offences may be brought under s.17 against an archbishop, any diocesan bishop, or any suffragan bishop commissioned by a diocesan bishop, or any other bishop, or a priest or deacon. Proceedings may be brought only when, at the time of the commission of the offence or when proceedings were instituted, the cleric held or holds preferment in any diocese or resided in a diocese. The first point to make is that doctrinal offences might not be committed by the laity or by lay ecclesiastical 
officers. It is arguable therefore that, on the face of it, because of the terms of the measure, and its exclusive application to the clergy, there is a fundamental right of dissent under church law (the common law of blasphemy excepted) vested in the laity and lay ecclesiastical officers. Indeed, with lay officers who are obliged to make a declaration of assent, the position is no different; proceedings for doctrinal offences cannot be brought against them simply because the canons of the Church of England are not, in law, binding on the laity. It seems to be a settled principle that the ecclesiastical courts do not possess jurisdiction to entertain suits against the laity. ${ }^{32}$

By s.15 the offence may be proceeded against only if committed "within the province of Canterbury or York". And by s. 16 there is a limitation period of three years for doctrinal offences: "No proceedings . . . shall be instituted unless the act or omission constituting the offence, or the last of them if the offence consists of a series of acts or omissions, occurred within the period of three years ending with the day on which proceedings are instituted."

This is an important point. If the doctrinal offence is based on a public dissent, a cleric's public challenge of the church's doctrine, there is a right to dissent (because the dissent will by operation of law not result in proceedings). The right operates retrospectively to cure an earlier illegality: it arises after the expiration of the limitation period. A cleric's otherwise illegal public expression of dissent is by law not actionable once a period of three years has elapsed since the dissent. In these circumstances, a doctrinal offence is incapable of being followed by ecclesiastical criminal proceedings. Again, the right to dissent is latent within the rule about limitation periods.

According to s.10, of course, proceedings for a doctrinal offence are to be heard in the Court of Ecclesiastical Causes Reserved. In exercising its jurisdiction this court, under s.45(3), is not bound by any decision of the Privy Council in cases involving doctrine. By s. 18 of the Ecclesiastical Jurisdiction Measure 1963 proceedings against archbishops or bishops must be by way of complaint laid before the registrar of the relevant province; and those against priests or deacons by way of complaint laid before the registrar of a diocese. Section 19 of the 1974 measure sets out a list of those having locus standi to make a complaint of a doctrinal offence against priests and deacons. These are "authorised complainants" (under s.66 one authorised by the bishop); in the case of incumbents of a parochial benefice, the complaint may be made by six or more persons of full age whose names are on the electoral roll; in the case of a stipendiary curate licensed to a benefice, the complaint may be made by the incumbent.

32. Halsbury, Ecclesiastical Law, para. 308; W. Dale, The Law of the Parish Church 6th ed. (1989), Chs. 4 and 5. For judicial recognition of the idea, see Lord Hardwicke's statement in Middleton v.Crafts (1736), discussed in The Report of the Archbishops' Commission on the Canon law of the Church of England (1947), and Blunt v. Park Lane Hotel Ltd. [1942] 2 K.B. 253. The canons will bind the laity only insofar as they are declaratory of the general law. They are, of course, binding on the clergy: see Bishop of Exeter v. Marshall (1868) L.R. 3 H.L. 17. 
Basically, in English church law, there are five doctrinal offences: heresy, blasphemy, depraving the prayer book, maintaining impious opinions contrary to the Christian religion, and doctrines repugnant to the Thirty-Nine Articles. ${ }^{33}$ The basis upon which a doctrinal offence might be committed, of course, is to challenge the statement, contained in the canons, that the doctrine of the Church of England is grounded in scripture, the teachings of the fathers and the councils as agreeable to the Word of God. Again the right to dissent is latent within the definitions of these offences, the areas to which the offence does not apply according to its terms, and it arises within the recognised defences to these offences: whenever an individual might legally be excused of his dissent; or when dissent is justified.

According to Burn, if a cleric advances publicly "a false opinion repugnant to some point of doctrine clearly revealed in scripture and either absolutely essential to the Christian faith or at least of most high importance", then he is guilty of heresy. ${ }^{34}$ The leading case is Williams v. Bishop of Salisbury (1864). ${ }^{35}$ Though it may still represent the law, we must be cautious about its practical applicability today. Williams was a clerk in holy orders and was prosecuted under the Church Discipline Act 1840 for publishing heretical doctrines in contravention of the Thirty-Nine Articles. These, the report says, were of a criminal nature. There were twenty-two charges against Williams, including his argument that the Bible is "an expression of devout reason", "the written voice of the congregation" and not "the Word of God", that the offering of Christ was not for the propitiation of the sins of the whole world. Williams was found guilty of the charges by the Arches Court. On an appeal from the Arches Court to the Privy Council, the Lord Chancellor set out some basic principles which help us to construct our right of dissent. They fall into two categories.

First, in relation to matters of doctrine on which the Church has not given any definite rule or standard of faith or opinions, the Lord Chancellor said, "there is so far freedom of opinion that they may be discussed without penal consequences." If a rule on a matter of doctrine is not "expressly and distinctly stated, or which is not plainly involved in or to be collected from that which is written", we might conclude that there is a legally enforceable right of free thought and free expression: in cases where the doctrine of the church is silent or neutral. Secondly, however, if the court is satisfied that an individual has committed heresy, still the dissent may be 'cured' if the procedural rules concerning the prosecution of heresy are not followed. The Privy Council's recommendation that Williams' sentence (given by the Arches Court) be reversed, was based on this ground. The Privy Council set down the procedural requirement that the articles of charge must

\section{See Halsbury, Ecclesiastical Law, para. 1354.}

34. R. Burn, Ecclesiastical Law 4th ed. pp. 304, 305.

35. (1864) 2 Moore P.C.C.N.S. 375. Our use of this case must be cautious. It is a Privy Council decision and under the Ecclesiastical Jurisdiction Measure 1963, ss. 45, 48, these decisions in matters of doctrine are no longer binding on the Court of Ecclesiastical Causes Reserved. It remains, however, a persuasive authority. 
distinctly state the opinions which the cleric maintains and must set out the published passages of the work in which the heretical statements appear. The articles of charge must specify the doctrines of the church which the individual's statements are alleged to contravene. In short, if these procedural rules are not followed by the church authorities in a doctrinal prosecution, then the accused escapes liability.

\section{Conclusion}

Disciplinary action taken in the Roman Catholic Church against Hans Küng and Johannes Metz, the lengthy investigations of theologians such as Schillebeeckx, and the debate in the Church of England over David Jenkins, Bishop of Durham, and John Robinson, Bishop of Woolwich and the author of Honest to God (1963), raise important questions about freedom of thought and expression in these churches. ${ }^{36}$ What is crucial to recognise is that these issues are fundamentally questions of canon law. The right of such people to freedom of thought and expression is determined by an analysis of the internal law of these churches. As disciplinary action by ecclesiastical authorities in the Roman Catholic Church is governed by the duty of assent to definitive doctrines, and the confused position of submission to non-definitive doctrines of the magisterium, so freedom of and expression is rooted in a right implicit in the exceptions to these duties and in the explicit right of dissent based on conscience. In the Church of England, though there are equivalent duties of assent to the church's doctrines, the basic legal principle is that any statement of doctrine not clearly offensive to the church's legally approved doctrines, or upon which the church's doctrines are silent, is not actionable in the ecclesiastical courts. The church possesses legal power to institute doctrinal proceedings. But, as a matter of fact, the ecclesiastical courts have not entertained such proceedings in recent years, even when these have seemed likely. For this reason it is tempting to conclude that something like an ecclesiastical convention has developed, fettering the use of these legal powers, giving to Synod rather than the courts the function of resolving such questions. Whatever the role of the difficulty in identifying whether a statment is offensive to ecclestiastical doctrine, an essentially theological problem, or whether inaction by church authorities is now explicable by means of ecclesiastical convention, in the final analysis, it is the canon law which, in the Church of England, and in the Roman Catholic Church, supplies the right to the individual's private and public withholding of assent to ecclesiastical doctrine.

36. For the Robinson controversy, see K. W. Clements, Lovers of Discord: Twentieth Century Theological Controversies in England (1988), pp. 178-217. For the Synod debates, sparked off by the Jenkins' controversy, see the General Synod February Group of Sessions 1985 Report of Proceedings, Volume 16, No. 1 (CIO Publishing, 1985), pp. 128-163, 171-182. 